\title{
A model approach for tritium dynamics in wild mammals
}

\author{
D. Galeriu and A. Melintescu \\ "Horia Hulubei" National Institute of Physics and Nuclear Engineering, Department of Life \\ and Environmental Physics, 30 Reactorului St., POB MG-6, Bucharest-Magurele, \\ RO-077125, Romania
}

\begin{abstract}
Tritium $\left({ }^{3} \mathrm{H}\right)$ transfer into environment must be modelled differently than the transfer of other radionuclides released from nuclear reactors because hydrogen represents the building blocks of life. A solid understanding of ${ }^{3} \mathrm{H}$ behaviour is essential because ${ }^{3} \mathrm{H}$ may be released in large quantities from CANDU (CANada Deuterium Uranium) reactors and from future thermonuclear reactors. Recently, the authors published a complex dynamic metabolic model for ${ }^{3} \mathrm{H}$ and ${ }^{14} \mathrm{C}$ transfer in farm and wild animals, but the model applications for wild biota were restricted to too few examples and mostly for ${ }^{14} \mathrm{C}$ transfer. In this study, the model is applied to few selected wild animals for ${ }^{3} \mathrm{H}$ uptake. Despite the lack of any experimental data for wild animals, the results presented in this study are less uncertain than for many other radionuclides and can provide a useful estimation for biota radioprotection.
\end{abstract}

\section{INTRODUCTION}

Radioprotection has historically focused on humans assuming that human protection includes nonhuman biota protection. Romania has CANDU nuclear reactors and one of the main concerns is tritium risk assessment, with a long debate concerning tritium human dosimetry. The experimental data of organically bound tritium (OBT) dynamics in humans are missing and consequently, the studies are focused on the development of a generic model for mammals in order to be further adapted for humans. A first step was to use hydrogen metabolism and animal nutrition in order to assess the transfer factors and concentration ratios for animal products for routine conditions and to test the model [1]. For human food chain modelling in case of tritium accidental emissions, the dynamical models were developed and successfully tested $[2,3]$. The basic idea was to use the energy metabolism to assess the OBT (and ${ }^{14} \mathrm{C}$ ) biokinetic rates for the whole body or for groups of tissues and/or organs. The model tests without any calibration reproduce the experimental data with a factor of less than 3 . The model was upgraded by adding the brain as a distinct compartment and was applied and successfully tested for human tritium dosimetry [4].

Biota radioprotection is also of concern [5-7]. For equilibrium conditions, a tritium application for wild animals was achieved [8]. The ${ }^{14} \mathrm{C}$ dynamics in few wild animals was previously considered [3]. The present efforts to demonstrate the protection of non-human biota consider the harmonization of a radioprotection framework for humans and non-human biota [9]. A general overview of the actual status is provided by international efforts (https://wiki.ceh.ac.uk/display/rpemain/IAEA), including the activities in biota working groups coordinated by International Atomic Energy Agency (IAEA). The reference animals and plants were internationally agreed [6] and the transfer parameters for routine cases were assessed (http://www-ns.iaea.org/projects/emras/emras2/ working-groups/working-group-five.asp?s=8). Recently, the requirements for the dynamic modelling within the environmental (i.e. wildlife) radiological assessments were reviewed [10] in order to cover the occurrence of pulsed discharges, decommissioning situation and accidents. The opinions about the usefulness of the dynamic models for wildlife are pointed out [10] and the main reliability issues seem to be limited to field data for parameterization and to limited test cases for validation. For 
Table 1. Input parameters; comparison between model and experimental data for BMR.

\begin{tabular}{|c|c|c|c|c|c|c|c|c|}
\hline \multirow[t]{2}{*}{ Animal } & \multirow[t]{2}{*}{ Latin name } & \multirow{2}{*}{$\begin{array}{r}\operatorname{mass} \\
(\mathrm{kg})\end{array}$} & \multirow{2}{*}{$\begin{array}{l}\text { exp. BMR } \\
\left(\text { MJ day }^{-1}\right)\end{array}$} & \multicolumn{3}{|c|}{ Exp. mass fraction } & \multirow{2}{*}{$\begin{array}{l}\text { calc. BMR } \\
\left(\mathrm{MJ} \mathrm{day}^{-1}\right)\end{array}$} & \multirow{2}{*}{$\begin{array}{l}\text { exp. FMR } \\
\left(\text { MJ day }^{-1}\right)\end{array}$} \\
\hline & & & & adipose & Muscle & viscera & & \\
\hline Lemming & $\begin{array}{c}\text { Lemmus } \\
\text { trimucronatus }\end{array}$ & 0.06 & 0.045 & 0.35 & 0.28 & 0.15 & 0.042 & 0.19 \\
\hline Chipmunk & $\begin{array}{l}\text { Tamias } \\
\text { striatus }\end{array}$ & 0.0915 & 0.0675 & 0.15 & 0.4 & 0.22 & 0.078 & 0.17 \\
\hline Rabbit & $\begin{array}{c}\text { Lepus } \\
\text { californicus }\end{array}$ & 1.8 & 0.57 & 0.1 & 0.43 & 0.13 & 0.573 & 1.3 \\
\hline Red fox & Vulpes vulpes & 6 & 1.1 & 0.15 & 0.45 & 0.13 & 1.43 & 4.5 \\
\hline $\begin{array}{l}\text { Red deer } \\
\text { (elk) }\end{array}$ & $\begin{array}{l}\text { Cervus } \\
\text { elaphus }\end{array}$ & 107 & 11.7 & 0.1 & 0.43 & 0.12 & 12.4 & 24.5 \\
\hline
\end{tabular}

the case of tritium, the present study uses a validated model for farm animals and limits the wild animals considered only to those examples for which the model parameters can be assessed with reasonable uncertainty.

\section{BRIEF MODEL DESCRIPTION, ANIMAL SELECTION AND INPUT PARAMETERS}

The full model description is given elsewhere [2,3] and the model structure was not changed for wild mammals. The wild specific mammals considered in this study (i.e. lemming, chipmunk, rabbit, red fox and red deer) are the same as for the ${ }^{14} \mathrm{C}$ case [3] and only tritium related aspects are discussed. A single compartment for body water is used for tritiated water (HTO), but many compartments are considered for OBT, as following: viscera with high metabolic rate, muscle, adipose, blood plasma, red blood cells and remainder. From the direct intake of dry matter into the stomach, only the metabolizable fraction (diet- and animal-dependent) is used and the rest is excreted to large intestine and faeces. From the total metabolisable fraction, the distinction between exchangeable and non-exchangeable organic tritium must be considered. Prior to digestion, the non-exchangeable fraction can be accounted knowing the diet composition, which generally is 0.6 to 0.74 , but digestion can decrease this value up to 0.4 for ruminants. In case of wild mammals, the approximate values are used. A part of the OBT input is lost through respiration and is transferred as HTO to body water. The OBT biological loss rate from organs and groups of organs is directly linked with the metabolic rate and the application to wild animal is described elsewhere [3]. In the present study, the coherent values for the body and organ mass and the measured Basal Metabolic Rates (BMR) were taken from literature and are given in Table 1, as well as a comparison with the modelled BMR. The agreement between calculated and measured BMR is reasonable, excepting the red fox. Field Metabolic Rate (FMR) is a measure of daily energy expenditure in field conditions and reflects the increases of energy needs due to activity for foraging. Both FMR and BMR are not only influenced by body mass, but by many other factors such as food habits, climate, habitat, and substrate [11]. Lemming in Arctic condition has a larger ratio FMR/BMR than the chipmunk. Carnivores (as red fox) have higher FMR/BMR ratios than herbivores. In Table 2 other input parameters are given concerning the body composition and the intake of food and water. The metabolisable and non-exchangeable fractions in the diet, being animal dependent, are also given.

\section{RESULTS}

The dynamic model can be used to check the equilibrium values of the concentration ratio (CR) given by a simple model [1]. The OBT concentration in the whole-body after HTO or OBT feeding was 
Table 2. Input parameters: body composition and animal intakes.

\begin{tabular}{|l|c|c|c|c|c|c|}
\hline Animal & $\begin{array}{c}\text { Body lipid } \\
\text { fraction }\end{array}$ & $\begin{array}{c}\text { Body protein } \\
\text { fraction }\end{array}$ & $\begin{array}{c}\text { Dry matter } \\
\text { intake }\left(\mathrm{kg} \mathrm{d}^{-1}\right)\end{array}$ & $\begin{array}{c}\text { Total water } \\
\text { intake }\left(\mathrm{L} \mathrm{d}^{-1}\right)\end{array}$ & $\begin{array}{c}\text { Metabolisable } \\
\text { fraction }\end{array}$ & $\begin{array}{c}\text { Non-exchangeable } \\
\text { fraction }\end{array}$ \\
\hline lemming & 0.30 & 0.13 & 0.019 & 0.019 & 0.74 & 0.6 \\
\hline chipmunk & 0.16 & 0.16 & 0.014 & 0.021 & 0.74 & 0.6 \\
\hline rabbit & 0.13 & 0.17 & 0.13 & 0.3 & 0.65 & 0.6 \\
\hline red fox & 0.16 & 0.16 & 0.25 & 0.3 & 0.77 & 0.7 \\
\hline red deer (elk) & 0.13 & 0.17 & 2.13 & 7.3 & 0.6 & 0.5 \\
\hline
\end{tabular}

Table 3. CR given by simple and dynamic model.

\begin{tabular}{|l|c|c|c|c|c|c|c|c|}
\hline Animal & \multicolumn{2}{|c|}{$\begin{array}{c}\text { CR whole-body } \\
\text { model) }\end{array}$} & \multicolumn{2}{c|}{$\begin{array}{c}\text { CR whole-body } \\
\text { model) }\end{array}$} & $\begin{array}{c}\text { CR adipose } \\
\text { (dynamic } \\
\text { model) }\end{array}$ & $\begin{array}{c}\text { CR muscle } \\
\text { (dynamic } \\
\text { model) }\end{array}$ & $\begin{array}{c}\text { CR viscera } \\
\text { dynamic } \\
\text { model) }\end{array}$ & $\begin{array}{c}\text { CR } \\
\text { remainder } \\
(\text { dynamic } \\
\text { model }\end{array}$ \\
\cline { 2 - 11 } & $\begin{array}{c}\text { OBT (HTO) } \\
\text { source) }\end{array}$ & $\begin{array}{c}\text { OBT (OBT }) \\
\text { source) }\end{array}$ & $\begin{array}{c}\text { OBT (HTO) } \\
\text { source) }\end{array}$ & $\begin{array}{c}\text { OBT (OBT }) \\
\text { source) }\end{array}$ & $\begin{array}{c}\text { OBT (OBT) } \\
\text { source) }\end{array}$ & $\begin{array}{c}\text { OBT (OBT }) \\
\text { source) }\end{array}$ & $\begin{array}{c}\text { OBT (OBT }) \\
\text { source) }\end{array}$ & $\begin{array}{c}\text { OBT (OBT) } \\
\text { source) }\end{array}$ \\
\hline lemming & 0.118 & 0.501 & 0.114 & 0.355 & 0.78 & 0.13 & 0.12 & 0.13 \\
\hline chipmunk & 0.081 & 0.345 & 0.073 & 0.302 & 1.02 & 0.18 & 0.15 & 0.21 \\
\hline rabbit & 0.073 & 0.312 & 0.065 & 0.174 & 0.66 & 0.12 & 0.10 & 0.16 \\
\hline red fox & 0.082 & 0.348 & 0.074 & 0.263 & 0.85 & 0.15 & 0.13 & 0.21 \\
\hline red deer (elk) & 0.083 & 0.354 & 0.063 & 0.264 & 1.02 & 0.18 & 0.16 & 0.23 \\
\hline
\end{tabular}

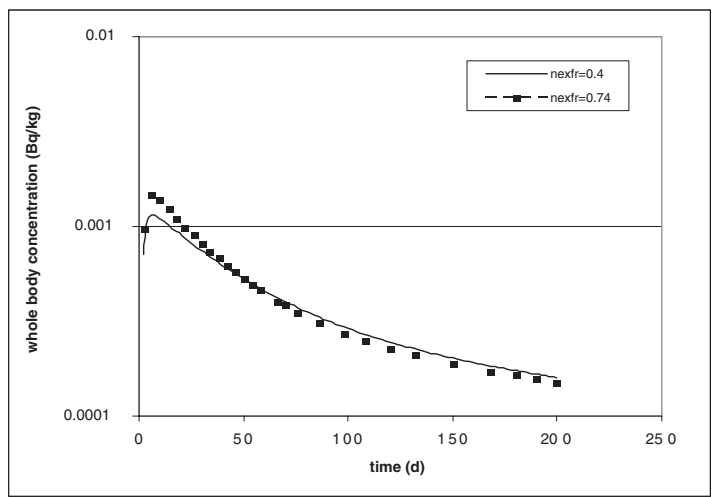

Figure 1. OBT dynamics in the whole-body of red deer for distinct values of OBT non-exchangeable fractions after digestion.

considered. The values given by the simple model are slightly higher (conservative) comparing to those given by the dynamic complex model (columns 2-5 in Table 3). The complex dynamic model also gives many details about CR variability for animal tissues. For the case of OBT intake (columns $6-9$ in Table 3), it is observed that the highest value is in adipose tissue. The whole body CR is definitely higher than for muscle.

An interesting case is the ingestion of OBT. As it was previously emphasised, the digestion changes the fraction of non-exchangeable OBT which is transferred to the body organic compartment. Figure 1 shows the maximal effect of digestion in the case of red deer and the OBT dynamics in the wholebody. A higher concentration is observed at the beginning for OBT non-exchangeable fraction in non-digested food (nexfr $=0.74$ ) than that one for ruminant digestion (nexfr $=0.4$ ). Later, the OBT non-exchangeable fraction for ruminant digestion $($ nexfr $=0.4)$ is higher than that one for non-digested food $($ nexfr $=0.74)$ and the net effect on the time integrated concentration is minor, less than $3 \%$. In its structure, the model includes the homeostatic control of hydrogen metabolism. 
Table 4. Model results.

\begin{tabular}{|l|c|c|c|c|c|c|c|c|}
\hline Animal & $\begin{array}{c}\text { Mass } \\
(\mathrm{kg})\end{array}$ & $\begin{array}{c}\text { Fast half- } \\
\text { time (d) }\end{array}$ & $\begin{array}{c}\text { Slow half- } \\
\text { time (d) }\end{array}$ & $\begin{array}{c}\text { Fast } \\
\text { contribution } \\
\text { in retention }\end{array}$ & $\begin{array}{c}\text { Effective half- } \\
\text { time }(\mathrm{d})\end{array}$ & $\begin{array}{c}\mathrm{TF}^{*} \text { whole- } \\
\left.\text { body }(\mathrm{d} \mathrm{kg})^{-1}\right)\end{array}$ & $\begin{array}{c}\mathrm{TF}^{*} \text { adipose } \\
\left(\mathrm{d} \mathrm{kg}^{-1}\right)\end{array}$ & $\begin{array}{c}\mathrm{TF}^{*} \text { muscle } \\
\left(\mathrm{d} \mathrm{kg} \mathrm{kg}^{-1}\right)\end{array}$ \\
\hline lemming & 0.06 & 1.33 & 45 & 0.8 & 1.5 & 18.7 & 40.9 & 7 \\
\hline chipmunk & 0.0915 & 3.2 & 46 & 0.9 & 3.5 & 21.3 & 71.8 & 12.4 \\
\hline rabbit & 1.8 & 5.5 & 65 & 0.87 & 6.3 & 1.34 & 5.1 & 0.89 \\
\hline red fox & 6 & 8.07 & 147.56 & 0.91 & 8.76 & 1.05 & 3.4 & 0.58 \\
\hline red deer & 107 & 24 & 194 & 0.83 & 28.6 & 0.124 & 0.48 & 0.084 \\
\hline
\end{tabular}

* Transfer factor.

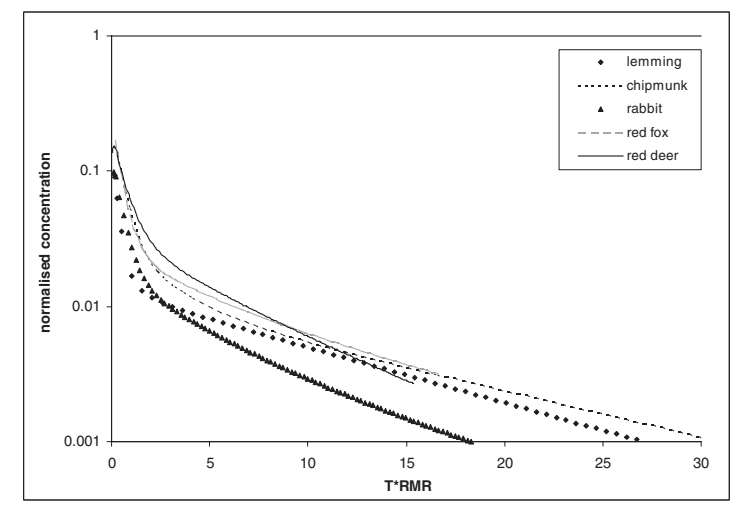

Figure 2. OBT dynamics in the whole-body (generalized coordinates) of various wild animals after an OBT intake.

The OBT dynamics in the animal whole-body after a single intake of OBT (1 Bq) depends on the animal mass, dietary habits and generally, can be analysed by bi-exponential decay with a fast and a slow half time. The model results are given in Table 4 and it is observed that the fast component prevails in the retention. The effective half time [3] increases with body mass, but a simple allometry is not enough, because the mass is not the only factor which affects the retention. It is observed that for an increase of body mass with more than three orders of magnitude, the fast component of the half time increases by a factor of less than 20 and the slow component increases with a factor of less than 5 . The transfer factors for the whole-body, adipose tissue and muscle are also given in Table 4 for a prolonged intake.

Due to a large mass difference between the selected mammals, it is preferable to represent the time dependence of the whole-body concentration in a convenient approach. A coordinate transformation is used by considering the same activity intake per $\mathrm{kg}$ of body mass, in order to have comparable concentrations and using a non-dimensional time scale in order to have a metabolic scaling (time on $\mathrm{x}$ axis becomes in generalised coordinates time multiplied by ReMR). ReMR (day ${ }^{-1}$ ) is a mammal average relative metabolic turnover rate, given by:

$$
\operatorname{Re} M R=0.073 * B W^{-0.266}
$$

where $\mathrm{BW}$ is the body weight $(\mathrm{kg})$.

The results for the OBT concentration in the whole-body are given in Figure 2 for the full period of interest. Even the lemming and chipmunk have comparable masses and it is observed a clear distinction in the dynamics (Figure 2), which can be explained by the differences in FMR/BMR ratio and fat content. In Figure 2, it is considered the metabolic scaling and it was taken into account that ReMR for red deer is $0.0211 \mathrm{day}^{-1}$, but for lemming is $0.1543 \mathrm{day}^{-1}$. 
Table 5. Concentration dynamics in grass.

\begin{tabular}{|l|c|c|}
\hline Time $(\mathrm{d})$ & HTO $\left(\mathrm{Bq} \mathrm{L}^{-1}\right)$ & OBT $\left(\mathrm{Bq} \mathrm{kg}^{-1} \mathrm{dm}\right)$ \\
\hline 0 & 4 & 2 \\
\hline 0.041667 & $7.27 \times 10^{7}$ & $1.50 \times 10^{5}$ \\
\hline 0.22 & $2.03 \times 10^{7}$ & $4.07 \times 10^{5}$ \\
\hline 1.22 & $7.57 \times 10^{5}$ & $5.53 \times 10^{5}$ \\
\hline 1.86 & $3.19 \times 10^{2}$ & $5.58 \times 10^{5}$ \\
\hline 6.48 & $1.59 \times 10^{2}$ & $5.36 \times 10^{5}$ \\
\hline 67.48 & 120 & $1.59 \times 10^{5}$ \\
\hline 112.48 & 16 & $6.37 \times 10^{4}$ \\
\hline 300 & 4 & $2.25 \times 10^{4}$ \\
\hline 360 & 4 & 2 \\
\hline 1000 & 4 & 2 \\
\hline & & \\
\hline
\end{tabular}

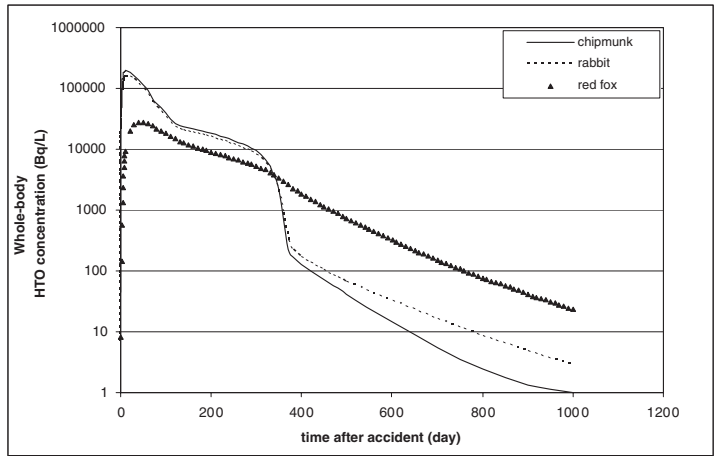

Figure 3. Dynamics of HTO concentration in body water for accidental condition in chipmunk, rabbit and red fox.

A potential application of the dynamic model is for accidental situations. In case of short term emission of HTO in large quantities, the vegetation contamination can be high and the relative HTO and OBT concentrations rapidly change in time after accident. In the first day, the animal intake is mostly as HTO, but soon, OBT will prevail. The initial HTO concentration in plant water can vary between $20 \%$ and $100 \%$ from that of HTO in air water vapour, depending on many factors (i.e. meteorology and stomatal resistance), but in less than 2 days, it decreases by more than 3 orders of magnitude. OBT in total vegetation reaches the maximum value few hours after the end of the atmospheric exposure and can be about $1 \%$ (water of combustion) from the maximum leaf water contamination. It will decrease due to respiration and partly can be transferred from leaves to seeds. For a hypothetical accident, the contamination of water HTO and plant OBT is given in Table 5.

It is proposed a food chain which considers the chipmunk and rabbit (which are herbivorousomnivorous) as prey and the red fox (which is a carnivore with an assumed diet consisting of rabbit $(30 \%)$ and chipmunk $(70 \%))$ as predator. The dynamics of HTO concentration in body water and of OBT concentration for the considered prey (rabbit and chipmunk) and the predator (red fox) are given in Figures 3 and 4, respectively.

In Figure 3, it is observed that the HTO concentration at the beginning is larger for prey than for predator, reaching its maximum after 2 weeks. In Figure 4, it is observed that OBT concentration at the beginning is larger for prey than for predator, reaching the maximum at day 30. Starting with day 90, the OBT concentration is higher than HTO concentration in prey and the body HTO concentration comes only from the OBT oxidation in the body. After day 300 there is no contaminated food for prey 


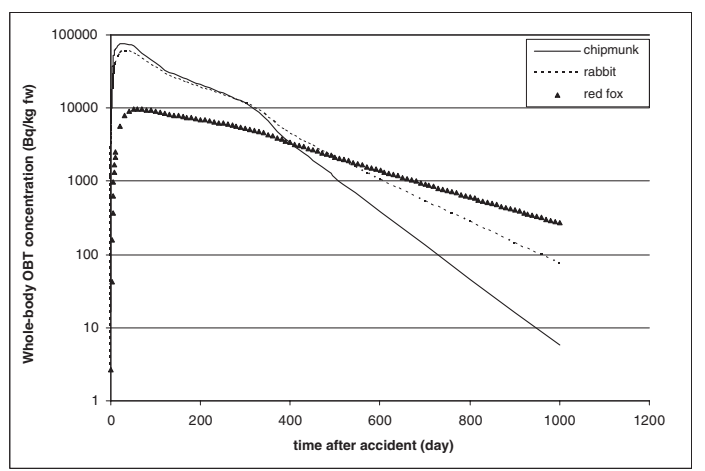

Figure 4. Dynamics of OBT concentration in whole body for accidental condition in chipmunk, rabbit and red fox.

Table 6. Integrated concentration in food and animal.

\begin{tabular}{|l|c|c|c|}
\hline type & $\begin{array}{c}\text { HTO } \\
(\mathrm{Bq} \mathrm{d})\end{array}$ & $\begin{array}{c}\text { OBT } \\
(\mathrm{Bq} \mathrm{d})\end{array}$ & $\begin{array}{c}\text { CR OBT } \\
(\text { OBT source })\end{array}$ \\
\hline vegetation & $2.10 \times 10^{7}$ & $3.83 \times 10^{7}$ & NA \\
\hline chipmunk & $1.54 \times 10^{7}$ & $1.16 \times 10^{7}$ & 0.305 \\
\hline rabbit & $1.32 \times 10^{7}$ & $1.03 \times 10^{7}$ & 0.27 \\
\hline fox food & $1.40 \times 10^{7}$ & $1.11 \times 10^{7}$ & NA \\
\hline fox & $4.60 \times 10^{6}$ & $3.35 \times 10^{6}$ & 0.30 \\
\hline red deer & $2.70 \times 10^{7}$ & $1.16 \times 10^{7}$ & 0.30 \\
\hline
\end{tabular}

(chipmunk and rabbit) and HTO concentration in body water suddenly decreases. The OBT whole-body concentration slowly decreases for prey and the decontamination is faster for chipmunk than for rabbit.

The tritium dynamics in prey and predators is different. The HTO concentration reaches the maximum later in predator than in prey, at day 40 and it is with about 8 times lower. After day 300, the HTO concentration slower decreases in predator than in prey, but the OBT concentration is higher in red fox than in prey. It is important to emphasize that after day 300, the HTO and OBT concentrations in predator are higher than in prey, opposite to the situation previously described. For an accidental case, it is important to compare the integrated concentrations in animals' food and animals bodies (Table 6) and it is observed that the integrated concentration ratios are close with those obtained for simple equilibrium conditions and the highest value is for red deer, while the lowest value is obtained for red fox. The effects of tritium radiation on animals are the same as for humans and the first physical quantity to assess the risk is the absorbed dose [6]. For tritium, considering a uniform distribution and

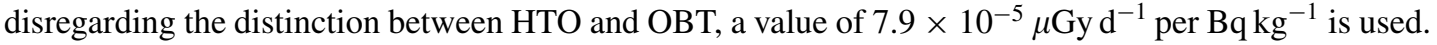
The model shortly described and used in the present study considers the distinction between HTO and OBT in both intake and body metabolism. Considering the total tritium concentration, the model gives the same absorbed dose rate for both forms of intake (HTO or OBT) at equilibrium. As for humans, the model can assess the ingestion dose conversion coefficients for intake of HTO or OBT.

\section{DISCUSSIONS AND CONCLUSIONS}

In this study, partial results are presented and further work on the dynamics of tritium in birds, as well as dosimetric and health effects are on going. It was emphasized that the dynamic model gives similar equilibrium concentration ratios, as the simple model [1] does and for accidental condition the integrated concentration ratios are similar, also. Using a metabolic scaling, the time dependence of 
whole-body concentration after a single OBT intake shows similar trend disregarding the large range of body masses. It was emphasized that for accidental conditions the dynamics in prey and predator differs and their decontamination is longer than for vegetation. Based on the present studies, the assessment uncertainty is not mainly based on the transfer between feedstuff and animal, but mostly on the vegetation contamination under accidental condition. Further research for biota tritium risk assessment must be focused on the population level and must consider the effects on reproduction and brain signal processing. If tritium is concentrated in the lipids of the brain cells membrane, the brain signals can be affected and the population survival will decrease due to decreased abilities for foraging and for avoiding the predators.

\section{References}

[1] Galeriu D., Melintescu A., Beresford N.A., Crout N.M.J., Peterson R., and Takeda H., J. Environ. Radioactiv. 98 (2007) 205-217

[2] Galeriu D., Melintescu A., Beresford N.A., Takeda H. and Crout N.M.J., Radiat. Environ Biophys. 48 (2009) 29-45

[3] Melintescu A and Galeriu D., Radiat. Environ. Biophys. 49 (2010) 657-672

[4] Galeriu D. and Melintescu A., J. Radiol. Prot. 30 (2010) 445-468

[5] ICRP, A Framework for Assessing the Impact of Ionising Radiation on Non-Human Species, ICRP Publication 91, Annals of ICRP 33 (3), Elsevier, 2003

[6] ICRP, Environmental Protection: the Concept and Use of Reference Animals and Plants, ICRP 1548, Publication 108, Annals of the ICRP 38 (4-6), Elsevier, 2008, 242 pages

[7] Beresford N.A., Hosseini A., Brown J.E., Cailes C., Beaugelin-Seiller K., Barnett C.L. and Copplestone D., J. Radiol. Prot. 30 (2010) 265-284

[8] Galeriu D., Beresford N.A., Melintescu A., Avila R., and Crout N.M.J., "Predicting tritium and radiocarbon in wild animals", International Conference on the Protection of the Environment on the Effects of Ionising Radiation, Stockholm, Sweden, 6-10 Oct. 2003, P. 186-189, IAEA-CN$109 / 85$

[9] Delistraty D., J. Environ. Radioactiv. 99 (2008) 1863-1869

[10] Vives i Batlle J., "Review of dynamic models for dose assessment of non-human biota analysis of questionnaire", Third Technical Meeting on the Environmental Modelling for Radiation Safety (EMRAS II), Working Group 4 "Biota Modelling", Vienna, Austria, 24-28 January 2011, http://www-ns.iaea.org/downloads/rw/projects/emras/emras-two/third-technicalmeeting/wgroup-four/presentation-5th-wg4-dynamic-modelling.pdf

[11] McNab B.K., Comp. Biochem. Phys. A, 151 (2008) 5-28 